\title{
Collateral Metabolites of the Aminosulphuric Acids in the Allium Plants
}

\section{Monica Butnariu*}

Banat's University of Agricultural Sciences and Veterinary Medicine "Regele Mihai I al Romanei” Timisoara, Romania- 300645, Calea Aradului 119, Timis, Romania

Allium cepa, Allium sativum and other representatives of Allium species contain $1-5 \%$ of non-proteic secondary biometabolites of the aminosulphuric acids. Some studies have demonstrated that stable precursor of the antibacterial principle of Cavallito is S-oxide (+ / -)-2-propenilcistein S (2). In the intact cell (2) S-oxide (Figure 1) of the $S$-alchenilcisteine (smell and flavor precursors) are located in the cytoplasm, while C-S lyase enzyme, in vacuole [1]. Following cell lysis takes place alpha / beta-elimination of the S-oxides allowing volatilization of low molecular weight such as organosulphur biocompounds (1).

In the Allium species four S-oxides appear: S-oxide S 2-propenyl, S-(E)-1-propenyl, S-methyl S-propyl-L-cysteine. A. cepa containing compounds (5-7) while Allium sativum containing substance (2), (5) and (6). Distinct plant flavors of Allium spp. reflect the variety of biocompounds, in particular the biocompound (5) ("isoallyl") which is the precursor of the lachrymatory factor $A$. cepa and the biocompound (2) which is a precursor to allyl biocompounds in characteristic $A$. sativum. Allium spp. plants contain gamma-glutamyl peptides 24 amino-aliphatic acids. Their main function is assumed to be the storage of nitrogen and sulfur biocompounds [2], and may play a role in the transport of amino acids through cell membranes. In the (Figure 2 ) is presented the biosynthesis of the peptides and flavor precursors based on experiments in which was induced A. cepa $\mathrm{SO}_{4}^{2-}$. Boiling the bulb of the plant or homogenizing the plant with alcohol, enzymes of Allium spp. may be disabled.

Sulfate is reduced and assimilated into the cysteine of the chloroplast to enter in the glutathione cycle. The addition of $\gamma$-glutamyl-1 cysteine in the methacrylic acid can lead to the $\gamma$-glutamyl-S-1-propenilcysteine, S-oxide oxidation $\gamma$-glutamyl-S-1-propenilcysteine, followed by cleavage of $\gamma$-glutamyl trans peptidase from the biocompound (5). Boiling the bulb of the plant or homogenizing the plant with alcohol, enzymes of Allium spp. may be disabled [3]. Sulfate is reduced and assimilated into the cysteine of the chloroplast to enter in the glutathione cycle. The addition of $\gamma$-glutamyl-1cysteine in the methacrylic acid can lead to the $\gamma$-glutamyl-S-1-propenilcysteine, S-oxide oxidation $\gamma$-glutamyl-S-1-propenilcysteine, followed by cleavage of $\gamma$-glutamyl trans peptidase from the biocompound (5).

Other experiments have demonstrated that the precursor (8) was converted to the precursor (5)-3-atom loss of the pro- $\mathrm{R}$ hydrogen and oxidative decarboxylation reaction occurs to the geometry anti analogously to the biosynthesis of terminal alkene (Figure 2) [4]. Parallel Processes involving the Michael addition of methacrylic acid, glutathione, resulting S-2-carboxy-glutathione (a), followed by conversion of the latter biocompound (8) and methylation of the resulting glutathione S-metilglutation (b) followed by conversion of finally the $\gamma$-glutamyl-S-methylcysteine (f). For A. sativum, the situation is less clear. The $\gamma$-glutamyl-S-2-propenilcisteina (c) formed from the precursor (8) or serine and more particularly from 2 propenetiol, a process to be elucidated; it is converted to $\gamma$-glutamylS-S-2-propenilcysteine oxide ( $g$ ) by oxidase and is then cleaved in the $\gamma$-glutamyl-transpeptidase (2). It has been reported that the concentration of $\gamma$-glutamyl-S-(S)-1-propenilcysteine (s) and $\gamma$ glutamyl-S-2-propenilcysteine (c) $\gamma$-glutamyl peptide prevailing in homogenates of fresh A. sativum, decreases when freshly picked $A$. sativum stored at $4^{\circ} \mathrm{C}$ [5]. The result of the storage of $A$. sativum in cold place is production of (5) and therefore the low molecular weight biocompounds containing organosulphur 1-propenyl group. Also, the A. sativum grown in cold climates contain much smaller amount of the biocompound (6) than in the temperate climates A. sativum increased, even though precursor biocompounds such as $\gamma$-glutamyl-Smethylcysteine (7) are in the normal range.

\section{Attraction / Repellent Effects on Insects and Animals}

Propantion sulfinate propyl, was identified as the most attractive biosubstance of crushed leaves of Allium porum (leek moths or Acrolepiopsis assectella, the caterpillars feed within the foliage and stems or bulbs of Allium spp. plants and related vegetables.). Propantion sulfinate propyl rejects Ephestia kuehniella. Allicin, counterparts like sulfur biocompounds Alliacee protect species of pathogens and predators. Concentrations of $2 \mathrm{ppm}$ of garlic oil components / metabolites diallyl disulfide trisulfide are toxic for mosquito and for larva of other insect and reject Ixodes ricinus, the tick carrier encephalitis virus [6].

Diallyl disulfide was also used for removal of a bird of prey cereal crops.

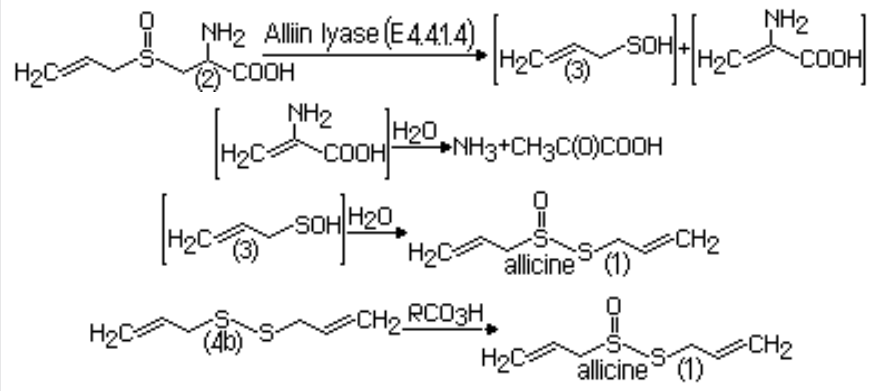

Figure 1: Allicin formation by alpha / beta-elimination of the S-oxides.

*Corresponding author: Butnariu M, Banat's University of Agricultural Sciences and Veterinary Medicine "Regele Mihai I al Romanei" Timisoara, Romania. 300645, Calea Aradului 119, Timis, Romania, Tel: +40-0-256-277; E-mail: monicabutnariu@yahoo.com

Received January 15, 2015; Accepted January 16, 2015; Published January 21 2015

Citation: Butnariu M (2015) Collateral Metabolites of the Aminosulphuric Acids in the Allium Plants. J Bioequiv Availab 6: e61. doi:10.4172/jbb.10000e61

Copyright: @ 2015 Butnariu M. This is an open-access article distributed under the terms of the Creative Commons Attribution License, which permits unrestricted use, distribution, and reproduction in any medium, provided the original author and source are credited. 


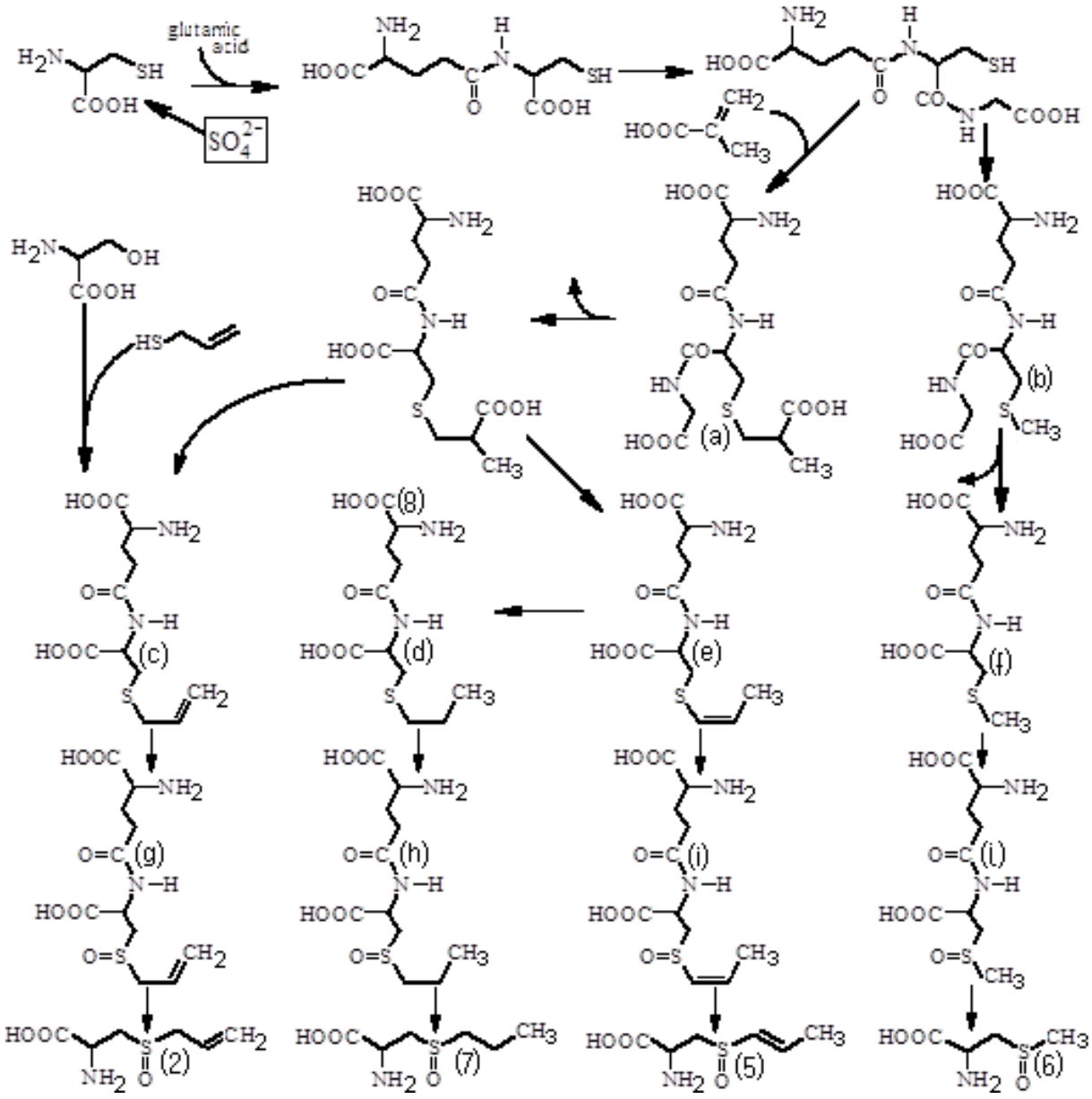

Figure 2: Biosynthesis of the peptides and flavor precursors based on experiments in which was induced $\mathrm{SO}_{4}{ }^{2}$ Allium cepa.

\section{References}

1. Putnoky S, Caunii A, Butnariu M (2013) Study on the stability and antioxidant effect of the Allium ursinum watery extract. Chem Cent J 7: 21.

2. Bagiu RV, Vlaicu B, Butnariu M (2012) Chemical composition and in vitro antifungal activity screening of the Allium ursinum L. (Liliaceae). Int J Mol Sci 13: $1426-1436$

3. Pentea M, Butnariu M (2014) The Organosulphur Composition of Allium Separated by Different Analytical Methods. Biochem Anal Biochem 3: e149.

4. Von White G II, Kerscher P, Brown RM, Morella JD, McAllister W, et al. (2012) Green Synthesis of Robust, Biocompatible Silver Nanoparticles Using Garlic Extract. J Nanomater 1-12.

5. Fujisawa H, Suma K, Origuchi K, Seki T, Ariga T (2008) Thermostability of allicin determined by chemical and biological assays. Biosci Biotechnol Biochem 72: 2877-2883.

6. Banerjee S, Hess D, Majumder P, Roy D, Das S (2004) The Interactions of Allium sativum leaf agglutinin with a chaperonin group of unique receptor protein isolated from a bacterial endosymbiont of the mustard aphid. J Biol Chem 279: 23782-23789. 